\title{
The Inner Circle: What is Diplomatic History? (And why we should study it).*
}

'I am still hoping that yesterday will get better.' Charlie Brown. ${ }^{1}$

It is unusual on occasions such as this to begin with a confession of ignorance; and yet I must do so. What exactly are inaugural lectures for? I do not know. I do not know whom or what they are to inaugurate. It is not the case that I lecture for the first time, either in this university or indeed in this room. I have documentary evidence to prove it! Nor is it the case that the subject of international history is new to this institution. On the contrary, it has a well-established pedigree, reaching back to the early years of the University.

So what am I inaugurating? I am inaugurating a chair, a professorship, and it is a most peculiar one. There is none like it in this country or anywhere else (as far as I know). And although many have sailed under the same flag, none was called Professor of Diplomatic History. The choice of nomenclature was mine; and it seems that I could hardly have chosen worse. For one thing, there is only one adjective, when most chairs have two, usually offering a more precise temporal or geographical definition. Worse, the adjective chosen - let us be honest - has a slightly oldfashioned ring to it. As if this was not bad enough, the subject, it has been suggested, is no better than 'the history of embezzlement or of robbing or poisoning ... . [It] is nothing but the history of international crime and mass murder!' ${ }^{2}$ Worse, it has been

\footnotetext{
* This is a revised version of the author's inaugural lecture as Professor of Diplomatic History on 29 Nov. 2016. The lecture format has been deliberately retained. The author has incurred a number of debts of gratitude in connection with this article, most notably to Zara Steiner, and further to Jeremy Black, Erik Goldstein, David Milne, Kristina Spohr and Jan Vermeiren.

${ }^{1}$ Charles M. Schultz, Peanuts strip, no. 699, 24 Mar. 1979.

${ }^{2}$ K.R. Popper, The Open Society and Its Enemies (2 vols., London, $4^{\text {th }}$ ed. 1963) ii, 270.
} 
dismissed as 'the most arid and sterile of all subdisciplines', thus adding to a sense of crisis. ${ }^{3}$ This is not a particularly recent development. There was much joy in certain circles when, in the early 1930s, the Royal Historical Society abandoned its Camden series in diplomatic history, though it came as no surprise to one of its most distinguished exponents, Sir Richard Lodge, who had noted 'that the mediaevalists ... [were] on the war path ... [and] just now in a peculiarly aggressive mood. ${ }^{\prime 4}$ It seemed, in G.M. Young's contemporaneous and oft-repeated put-down, that diplomatic history was 'little more than the record of what one clerk said to another. ${ }^{5}$ Did it not epitomize the 'ossification of constructive historical thinking'?; and did not even its most prominent practitioners, such as A.J.P. Taylor, have little more to offer than '[f]act accumulation, moralizing and liberal variants of the idea of progress' ${ }^{6}$ ? Worse still, all too often it seemed accompanied by an unhealthy dose of elitism ${ }^{7}$, and a belief in 'great men' and their deeds. As for these great, and often less than great, men - and occasionally women, too - as a recent reviewer in one of the Sunday papers noted, '[d]iplomacy is an unfashionable activity, and those who practise it are treated with some contempt by politicians, ${ }^{8}$ - and, one is compelled to add, not merely by them. And yet, now more so than ever before, 'the international dimension is one of

\footnotetext{
${ }^{3}$ A. Marwick, The Nature of History (London, 1970), 93.

${ }^{4}$ Lodge to Horn, 20 Apr. 1930, Lodge MSS, Edinburgh University Library, Gen 766/1. This was the Camden series British Diplomatic Instructions, 1689-1789, of which seven volumes appeared between 1922 and 1934, and which covered relations with Denmark, France and Sweden. For mediaevalist jubilations see M. Bentley, Modernizing England's Past: English Historiography in the Age of Modernism, 1870-1970 (Cambridge, 2005), 84.

${ }^{5}$ G.M. Young, Victorian England: Portrait of an Age (London, 1936), 103.

${ }^{6}$ G. Stedman Jones, 'History: The Poverty of Empiricism', in R. Blackburn (ed.), Ideology in Social Sciences: Readings in Critical Theory (London, repr. 1974 (pb)), 108 and 111.

${ }^{7}$ Pertinent G. Himmelfarb, "“History with the Politics Left Out” (Postscript)', in id., The New History and the Old: Critical Essays and Reappraisals (Cambridge, MA, 1987), 26-32.

${ }^{8}$ M. Hastings review of Sir J. Greenstock’s Iraq: The Cost of War, Sunday Times, 30 Oct. 2016.
} 
the crucial problems of the contemporary era', one that profoundly shapes twentyfirst-century states and societies. ${ }^{9}$

A defence, then, is necessary, an assertion of the justness and the relevance of the subject. When writing his memoirs, a former senior Foreign Office official, decided to call the fruits of his literary labours The Inner Circle, falling back on an old FO joke - a mild one even by the standards of that genre - according to which the diplomatic service was likened to the London Underground: 'once a man was launched on the Inner Circle (London, Paris, Berlin, Rome) it was impossible to leave the track. ${ }^{10}$ Let us embark on a similar journey around the discipline.

There is an undeniable degree of tension between the two considerations of justness and relevance. What follows is not to be read as a 'relevantine' manifesto, for the intellectual justification of a subject - and hence its intrinsic legitimacy - cannot and should not be determined by its practical value per se.

The notion of the practical relevance of studying history has nevertheless a long pedigree. The etymological root of the word, indeed, implies knowledge obtained through systematic exploration and disseminated by means of a narrative. ${ }^{11}$ History, as an intellectual endeavour, is thus an attempt 'to cast time into thought'.

\footnotetext{
${ }^{9}$ G. Formigioni, Storia della politica internazionale nell'età contemporanea (Bologna, 2000), 9; see also the reflections offered by Sir Christopher Mallaby in his memoirs, Living the Cold War: Memoirs of a British Diplomat (Stroud, 2017), 12-18.

${ }^{10}$ Sir I. Kirkpatrick, The Inner Circle: Memoirs (London, 1959), x.

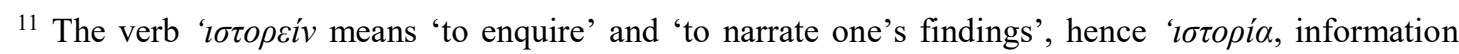
obtained through enquiry. It is interesting to ponder its relation $i \sigma \tau \sigma \sigma$, the (woven) web, Liddell and Scott's Greek-English Lexicon (Oxford, abbr. ed. 1974), 335. For further thoughts see also M. Heidegger, 'Wissenschaft und Besinnung', in id., Vorträge und Aufsätze (Pfuhlingen, 1954), esp. 5960 .
} 
'When traversing the past, ... we are concerned with the present. ${ }^{12}$ History, then, as Johan Huizinga noted, is 'the intellectual form in which a culture renders to itself an account of its past.' ${ }^{13}$ The belief in applicable 'lessons of history', of course, reaches back to the earliest attempts at understanding the past. There was - and still is - a general assumption that the fruits of the historian's labours should be a Gesta Romanorum-type 'stock of instances and illustrations with the edifying conclusion: "And this, my friends, ought to teach us!" 14 Thucydides wrote an account of the Peloponnesian war because that conflict 'was more important than any that preceded it', and because he thought he had discerned certain recurring patterns in the history of mankind. ${ }^{15}$ Similarly, Machiavelli’s Florentine history and other writings were stimulated by a strong sense of contemporary crisis and were based on analogous assumptions - here the cyclical course of history - and on the belief that it was possible to distil key elements of statecraft from the study of the past. ${ }^{16}$

This aspiration applied more especially also to diplomatic history as the study of the principal activity of states. Following the reconstitution of Europe after the

12 G.W.F. Hegel, Die Vernunft in der Geschichte, ed. J. Hoffmeister (Hamburg, 5 ${ }^{\text {th }}$ ed. 1955) (= Sämtliche Werke: Neue Kritische Ausgabe XVIII A), 16 and 183.

13 J. Huizinga, 'Over een definitie van het begrip geschiedenis', Mededeelingen der Koninklijke Akademie van Wetenschapen, Afdeeling Letterkunde, ser. B. no. 2 (1929), 40. Huizinga stressed the rational and pragmatic nature of the exercise, ibid., 41; on this see also Haller to Huizinga, 12 Aug. 1929, and vice versa, 15 Aug. 1929, L. Hanssen, W.E. Krul and A. van der Lem (eds.), Johan Huizinga: Briefwisseling (3 vols., Utrecht, 1989-91) ii, nos. 819-820.

${ }^{14}$ W. Paton Ker, On the Philosophy of History: An Address Delivered to the History Society, University of Glasgow, January 8, 1909 (Glasgow, 1909), 9; see also the reflections by G. Connell-Smith and H.A. Lloyd, The Relevance of History (London, 1972).

15 Thucydides, Istorion A, ed. E.C. Marchant (London, 1964), bk. I, cc. 22-3. The use of the word $\mu \varepsilon \dot{\gamma}$ lıov to characterize the war is open to interpretation; it may also mean 'greater'. Thucydides said that his work was an $\omega \varphi c ́ ́ \lambda \iota \mu \alpha$ (aid) to the reader to examine the past and to interpret the future more wisely, ibid.; see also H.R. Rawlings III, The Structure of Thucydides' History (Princeton, NJ, 1981), 254-255; J. de Romilly, 'L'utilité de l'histoire selve Thucydide', id., L'invention de l'histoire chez Thucydide (Paris, repr. 2017), 15-30.

${ }^{16}$ N. Machiavelli, Opere, ed. C. Vivanti (3 vols., Turin, 1997-2005) iii, 519 and 629 (books 1 and 7); E. Cassirer, Der Mythus des Staates (Zürich, 1949), 170-183; F. Gilbert, Machiavelli and Giucciardini: Politics and History in Sixteenth-Century Florence (New York, repr. 1984), esp. 255-270. 
Napoleonic Wars, Leopold von Ranke postulated the primacy of foreign policy: 'Its position in the world confers upon a state the degree of its independence; it thus is faced with the necessity of arranging its internal affairs with a view to maintaining itself [abroad]. That is its supreme law. ${ }^{, 17}$ Indeed, in Britain and well before Ranke, King George I founded the Regius professorship of history not so much to advance learning, but as 'a protective measure against the importation of foreign and better educated tutors' - little did the Hanoverian know - and to train young men 'capable of serving the King at home and abroad' ${ }^{18}$

A century-and-a-half later, the then occupant of the chair, Sir John Robert Seeley, argued that 'history should pursue a practical object ... . [I]t should not merely gratify the reader's curiosity about the past, but modify his views of the present and the forecast of the future. [...] Some large conclusions ought to arise out of it.' History therefore had a special place in education. It was nothing less than 'the school of statesmanship.' ${ }^{19}$ Such views remained de rigueur for some considerable time. G.W. (later Sir George) Prothero, Seeley's amanuensis and later the first official historical adviser at the Foreign Office, argued that 'history is the mother, in more senses than one, of politics', and that an historical education was especially 'proper for the citizen

\footnotetext{
${ }^{17}$ L. von Ranke, 'Das politische Gespräch [1836]', in id., Geschichte und Politik, ed. H. Hoffmann (Stuttgart, 1942), 97. Ranke was too subtle a thinker to embrace any form of determinism. The interaction between the internal and external spheres was one of the 'most varied effect and countereffect', just as history was more than an 'accidental chaos [Durcheinanderstürmen], falling upon and succeeding one another of states and peoples', in id., 'Die grossen Mächte [1833]', id., Zwölf Bücher preussischer Geschichte, vorangestellt Die Grossen Mächte, ed. W. Andreas (2 vols., Hamburg, 1957) i, 10 and 36; see also E. Schulin, 'Universalgeschichte und Nationalgeschichte bei Leopold von Ranke', in W.J. Mommsen (ed.), Leopold von Ranke und die moderne Geschichtswissenschaft (Stuttgart, 1988), 68-69.

18 B. Williams, The Value of History: An Inaugural Lecture delivered before the University of Edinburgh on 14 ${ }^{\text {th }}$ October, 1925 (Glasgow, 1925), 5.

19 J.R. Seeley, The Expansion of England: Two Courses of Lectures (London, $2^{\text {nd }}$ ed. 1899 [1 $\left.{ }^{\text {st }} 1883\right]$ ), 1; and id., 'The Teaching of Politics: An Inaugural Lecture Delivered at Cambridge [1869]', id., Lectures and Essays (London, 1895), 325. Across the Atlantic, Henry Cabot Lodge took a very similar view, see W.C. Widenor, Henry Cabot Lodge and the Search for an American Foreign Policy (Berkeley, CA, 1980), 4-43.
} 
of a self-governing State.' ${ }^{20}$ C.K. (later Sir Charles) Webster, Stevenson Chair of International History at the LSE, reflected in his inaugural lecture that ' $\mathrm{h}$ ] istory itself has been one of the greatest influences on the course of international affairs. The great men of action have always used it to test and train themselves. ${ }^{21}$

As an established sub-discipline international history is of more recent vintage. It came into its own after the First World War, and it was only in the 1970s that it acquired, in Zara Steiner's felicitous phrase, 'the contemporary attributes of [academic] adulthood', that is university departments, scholarly journals, professional bodies and conferences dedicated to its study. ${ }^{22}$ There was nonetheless always an understanding that the emerging field was no 'pure' history, that it had more than strictly scholarly values and aspirations, and that it was pursued not just for its own sake. More especially in its early phase it was a form of 'disaster studies'. ${ }^{23}$ The defeat and demise of the Second Empire in 1870 was an important intellectual spur for Albert Sorel, one of the pioneers of diplomatic history. His study of Europe and the French revolution, the massif central of contemporary French scholarship, was also a national counterpoint to Heinrich von Sybel's no less monumental account of that

\footnotetext{
${ }^{20}$ G.W. Prothero, 'Presidential Address', Transactions of the Royal Historical Society, n.s. xvi (1902), viii; for Prothero's role see E. Goldstein, “"A prominent place would have to be taken by history": The Origins of a Foreign Office Historical Section', in T.G. Otte (ed.), Diplomacy and Power: Studies in Modern Diplomatic Practice. Essays in Honour of Keith Hamilton (Dordrecht, 2012), 83-102.

${ }^{21}$ C.K. Webster, 'The Study of International History', History xviii, 70 (1933), 113.

${ }^{22}$ Z.S. Steiner, 'On Writing International History: Chaps, Maps and Much More', International Affairs lxxiii, 3 (1997), 531; see also her important autobiographical reflections, 'Beyond the Foreign Office Papers: The Making of an International Historian', International History Review xxxix, 3 (2017), 546570; further E. Serra, Manuale di Storia dei trattati e di diplomazia (Milan, 1980), 26-27.

${ }^{23}$ D.C. Watt's memorable phrase, id., What About the People?: Abstraction and Reality in History and the Social Sciences (London, 1983), 4.
} 
period, a work that made France responsible for the bellicosity of those years and that itself reflected a sense of German vulnerability in mid-century. ${ }^{24}$

The First World War reinvigorated the discipline. Many of the leading international historians of the inter-war and early Cold War years had seen active service at the front or in intelligence. Pierre Renouvin and Egmont Zechlin, both of them maimed in the war, were representative of French and German scholarship. ${ }^{25}$ In Britain, it was secondment to Whitehall or political and military intelligence that sharpened an understanding that history mattered, and that it was an indispensable ingredient in the process of framing a strategic vision. The careers of Webster and Lewis Namier spring to mind, and so does that of Harold Temperley, who served in War Office intelligence. ${ }^{26}$ History, he reflected during the war, bound together military matters and diplomatic questions: 'The political side of strategy requires a

\footnotetext{
24 A. Sorel, L'Europe et la Révolution française (8 vols., Paris, 1885-1904), and H. von Sybel, Geschichte der Revolutionszeit von 1789 bis 1800 (5 vols., Düsseldorf, 1853-79); for further thoughts on these two historians see J. Bariéty, 'Albert Sorel: L'Europe et la Révolution française, 1885-1904', in id. (ed.), 1889: Centenaire de la Révolution française (Berne, 1992), 129-144; and H. Seier, 'Heinrich von Sybel', in H.-U. Wehler (ed.), Deutsche Historiker (8 vols., Göttingen, 1971-82) ii, 2438.
}

25 For Renouvin, see S.W. Halperin, Some Twentieth-Century Historians: Essays on Eminent Europeans (Chicago, IL, 1961), 143-170; for Zechlin, see his early memoirs, id., Erlebtes und Erforschtes 1896-1919, ed. A. Zechlin (Göttingen, 1993), and also D. Freese, 'Egmont Zechlin (18961992): Biographische Studie eines Historikers vom Kaiserreich bis zum Ende des Nationalsozialismus, zwischen wissenschaftlicher Autonomie und politischer Anpassung' (Ph.D. thesis, Carl-von-Ossietzky University Oldenburg, 2004).

${ }^{26}$ C.K. Webster, 'Draft Autobiography' (TS), n.d. [c. 1950s], Webster MSS, London School of Economics Archives, 23/6. For the role of historians in wartime intelligence see E. Goldstein, Winning the Peace. British Diplomatic Strategy, Peace Planning, and the Paris Peace Conference 1916-1920 (Oxford, 1991). Temperley was head of MI2E, later renamed MI6B, which dealt with 'the political side of problems of the [peace] settlement', see anon., 'Sketch of the History of the Military Section, British Delegation, Congress of Paris, December 1918 - July 1919', Sept. 1919, Temperley MSS, private. For Temperley's career in intelligence see J.D. Fair, Harold Temperley: A Scholar and Romantic in the Public Realm (London and Toronto, 1992), 105-146, and T.G. Otte, 'Introduction', in id. (ed.), An Historian in Peace and War: The Diaries of Harold Temperley (Farnham and Burlington, VT, 2014), 23-29 et passim. 
knowledge which cannot be improvised and is based on the study of history and a considerable acquaintance with contemporary politics, economics, and diplomacy. ${ }^{27}$

Such views played a role in fighting the war at the grand strategic level, and continued to do so in the immediate aftermath of the conflict. A number of historians came together in 1919 to found the British (now Royal) Institute of International Affairs. A few were well established, many more were in mid-career, but all had earned their spurs in war-time intelligence and all would make names for themselves in academia. Among them were E.H. Carr (then still a serving diplomat), James Headlam-Morley, Namier, Prothero, R.W. Seton-Watson, B.H. Sumner, Temperley and Webster as well as the two classicists Arnold J. Toynbee and Alfred Zimmern. ${ }^{28}$ Soon Chatham House forged a cadre of largely historically trained international relations specialists. The institution's activities played a significant role in extending the scope of British foreign policy in the twentieth century. ${ }^{29}$ University teaching, too, reflected the wave of post-1919 internationalism and was very much focused on the demands of the present. 'We are seriously endeavouring', wrote Temperley (back in Cambridge since the autumn of 1919), 'to turn the serious attention of our young men

\footnotetext{
${ }^{27}$ Temperley, 'War Notes: Montenegro - Strategy', n.d. [1915-6], Temperley MSS, private. Temperley did not hold back with such views: 'Temperley came with a suggestion that we should have a small historical staff to look into the past history of some debatable questions more particularly in the Balkans and Poland, which will come up at the Peace Conference', Amery diary, 3 Feb. 1917, J. Barnes and D. Nicholson (eds.), The Leopold Amery Diaries, 1896-1929 (London, 1980), 141.

28 'Report of the Provisional Committee appointed to prepare a Constitution, and select the original members of the British Branch of the Institute of International Affairs', n.d. [1919], Headlam-Morley MSS, Churchill College Archive Centre, Cambridge, HDLM Acc.727/43. Chatham House was inaugurated on 5 July 1920; see also M. Mazower, No Enchanted Palace: The End of Empire and the Origins of the United Nations (Princeton, NJ, 2009), 66-103; D. Stevenson, 'Learning from the Past: The Relevance of International History', International Affairs xc, 1 (2014), esp. 6-10; T.G. Otte, "“The Light of History": Scholarship and Officialdom in the Era of the First World War', Diplomacy \& Statecraft xxx, 2 (2019), 253-287.

${ }^{29}$ D.C. Watt, Personalities and Policies (London, 1965), 48; see also the official history, S. King-Hall, Chatham House: A Brief Account of the Origins, Purposes, and Methods of the Royal Institute of International Affairs (London, 1937), 10-26.
} 
in the direction of International Politics and the League of Nations. ${ }^{30}$ Indeed, he exhorted the contributors to his multi-volume official history of the peace conference 'to adopt a Geneva perspective' and to present the 1919 settlement as 'a great experiment'. ${ }^{31}$

Faith in the 'Geneva perspective' and the practical wisdom imparted by the study of history soon dissipated. Internationalism and the League did not prevail. In the vanquished and the victorious countries alike, historians laboured under a selfimposed patriotic duty to exculpate their nation from any 'war guilt'. Renouvin and Zechlin serve as examples here, though both mellowed in later years. Moreover, neither in Britain nor elsewhere did international history establish itself as the jewel in the crown of the historical profession. Temperley, who had entertained hopes for the Regius chair in 1927, had to acknowledge that G.M. Trevelyan's appointment meant 'good-bye to the day dreams of enthroning Modern and Diplomatic History on the Regius Chair.' 32

Yet the field continued to grow; and it has by now outgrown the confines which Webster and Temperley knew. Later generations, especially in Britain, resorted to the neologism of 'international history' to signify interest not just in the deeds of politicians and bureaucrats but in broader historical patterns, including financial ties

\footnotetext{
${ }^{30}$ Temperley to Gennadius, 8 Nov. 1919, Gennadius MSS, American School of Classical Studies, Athens, folder 6/5. He later rowed back, asserting that '[h]istory should be studied for herself alone. The appeal history makes is both intellectual and emotional but it is limited and objective in its scope, and becoming more so', id., Research and Modern History: Inaugural Lecture delivered at Cambridge, November $19^{\text {th }}, 1930$ (London, 1930), 18.

${ }^{31}$ Memo. Temperley, 'Suggestions to Contributors', n.d. [1919], Webster MSS, 1/3/30; but see also his 'Editorial Foreword', in id. (ed.), A History of the Peace Conference of Paris (6 vols., London, 1920-1) $\mathrm{i}, \mathrm{X}$, in which he stressed the aim of striving to be 'as moderate, detached, and impartial as possible'.

${ }^{32}$ Temperley to Webster, 20 July 1927, Webster MSS, 1/9/43; D. Cannadine, G.M. Trevelyan: A Life in History (London, 1993 (pb)), 16.
} 
and intellectual currents, commerce and the military. ${ }^{33}$ In fact, the field has grown so much that one distinguished historian of American foreign relations concluded that '[i]nternational history is so broad a term that it loses its usefulness.' ${ }^{34}$

Our Circle Line train, it seems, has now left the track somewhere around Aldgate and is hurtling towards Whitechapel or some other station at the back of beyond. How can we get it back onto the right track without resorting to Mornington Crescent-style leaps of the imagination? For there is no denying that the field has come under attack from within and without. It has become contested, and so have many of its methods.

Let us pause here and remind ourselves what, at its core, international history is before turning to the challenges it faces. 'Diplomacy, like water colours, suffers from the fascination it exerts on amateurs ${ }^{35}$ - I will resist the temptation of making reference here to current affairs. It is what one might call the 'ferrero rocher fallacy', which leads some to mistake the glittering wrapper for its inner essence. This applies to not a few who have practised diplomatic or international history, and even more so to their critics. Foreign policy was and, as current events confirm, remains one of the most important functions of state activity. It was and is also one that reveals the operations of the given political system. Historically, foreign affairs helped to crystallize thinking about contending notions of the national interest, thus articulating

\footnotetext{
${ }^{33}$ P.M. Kennedy, The Realities behind Diplomacy: Background Influences on British External Policy, 1865-1980 (London, 1980), 17-36 et passim; A. de Conde, 'Essay and Reflection: On the Nature of International History', International History Review x, 2 (1988), 282-301; D. Reynolds, 'International History, the Cultural Turn and the Diplomatic Twitch', Cultural and Social History iii, 1 (2006), here 77-78.

${ }^{34}$ T.G. Paterson, 'Defining and Doing the History of American Foreign Relations: A Primer', Diplomatic History xiv, 3 (1990), 585.

${ }^{35}$ H. Nicolson, Curzon: The Last Phase, 1919-1925 (London, 1934), 54.
} 
ideological ideas and associating them with specific political groupings. ${ }^{36}$ Collingwood's observation that the scholarly pursuit of history amounts to a 'reenactment of past experience' is pertinent here. ${ }^{37}$ International history is concerned primarily with events, and to that end its students compose, as A.J.P. Taylor did, timelines and diaries of the actions of the participants so as to create a tight chronology of intersections to reconstruct decision-making and thereby to recover the dynamic of past situations. ${ }^{38}$

Two further considerations are linked to this. It is necessary to study international history from at least a bilateral, preferably from a multilateral, perspective. The problem with foreign affairs, of course, is that they involve dealing with foreigners. This is not a 'Little Englander' lament at the undue influence of other, presumably, 'lesser breeds'. It is simply an acknowledgment of an incontestable fact. Different cultural contexts, historical experiences and geographical locations explain how and why different countries form differing views of a particular matter, see it in relation to diverse objectives, and frame distinct policy responses to it. Such experiential differences can be quite sharply developed, as the late Bernard Lewis showed in his thought-provoking work on the Islamic world and Jürgen Osterhammel

\footnotetext{
${ }^{36}$ This is particularly pertinent for the eighteenth century, see J.M. Black, British Foreign Policy in an Age of Revolutions, 1783-1793 (Cambridge, 1994), 472-518; but it holds equally true of later periods, see e.g. M. Swartz, The Politics of British Foreign Policy in the Era of Disraeli and Gladstone (London, 1985); R. Vickers, The Labour Party and the World: The Evolution of Labour's Foreign Policy, 1900-1951 (Manchester, 2003); and K. Neilson, Britain, Soviet Russia and the Collapse of the Versailles Order, 1919-1939 (Cambridge, 2006), 13-8 and 40-42; further J.-J. Becker, 'L'opinion publique fraçaise a-t-elle eu une influence sur la politique extérieure de la France lors de la crise de juillet 1914?', in P. Levillain and B. Vigezzi (eds.), Opinion Publique et Politque Extérieure (Rome, 1981), 207-222.

${ }^{37}$ R.G. Collingwood, The Idea of History (Oxford, 1946), 9; for a critical discussion of Collingwood's notion and the debates surrounding it, see W.H. Dray, History as Re-Enactment: R.G. Collingwood's Idea of History (Oxford, 1999).

${ }^{38}$ See the reflections on this by one of Taylor's disciples and biographer K.M. Burk, Troublemaker: The Life and History of A.J.P. Taylor (New Haven, CT, 2000), 288; and C. Wrigley, A.J.P. Taylor: Radical Historian of Europe (London, 2006), 75-77.
} 
or Odd Arne Westad have done in their books on China. ${ }^{39}$ Even in the more familiar European context, such differences, though often nuanced and subtle, are still significant. I need not labour the point - following current affairs will suffice. As Hegel wrote, 'without relations with other states, the state can no more be an actual individual than an individual can be an actual person without a relationship with other persons. ${ }^{40}$ Just as a football reporter cannot capture the dynamics or the flow of the match, the intricacies of the passing game or the effectiveness of counter-pressing by focusing on just one team, so the historian cannot simply concentrate on one side alone. To do so would feed a higher form of parochialism, one of the besetting sins of this country.

The second consideration is that ' $[\mathrm{w}] \mathrm{e}$ must never separate the study of policy ... from the appreciation of the instruments on the understanding and the use of which success depends; and we must test the character of the instruments by the work they do. ${ }^{41}$ International history, then, requires a certain degree of technical and linguistic competence, an appreciation of cultural subtleties and an understanding of the different ways in which states are organized and interact with each other. ${ }^{42}$ But amidst all the aides mémoires, bouts de papiers and notes verbales, one must not lose sight of the official apparatus through which international relations were conducted. Foreign ministries are 'knowledge-based organisations', political nerve centres where

\footnotetext{
${ }^{39}$ B. Lewis, Islam and the West (Oxford, 1993), and Notes on a Century: Reflections of a Middle East Historian (London, 2013 (pb)), 228-265; J. Osterhammel, China und die Weltgesellschaft: Vom 18. Jahrhundert bis in unsere Zeit (Munich, 1989); O.A. Westad, Restless Empire: China and the World since 1750 (Newport, CT, 2012).

${ }^{40}$ G.W.F. Hegel, Grundlinien der Philosophie des Rechts, ed. G. Lasson (Leipzig, 1911), §332, p. 267; for the context see F. Rosenzweig, Hegel und der Staat (2 vols., Aalen, repr. 1962 [1 $\left.{ }^{\text {st }} 1920\right]$ ), ii, 172175.

41 D.P. Heatley, Diplomacy and the Study of International Relations (Oxford, 1919), 4-5; worth contemplating also H. Butterfield, 'In Defence of Diplomatic History', unpubl. MS, n.d. [1950s], Butterfield MSS, Cambridge University Library, BUTT/426.
}

${ }^{42}$ See M.S. Anderson, The Rise of Modern Diplomacy, 1450-1919 (London, 1993), viii-x. 
information gathered by the diplomats abroad is stored, analysed and retrieved so as to ensure informed decision-making. 'Red Tape', enthused another diplomat of the period, 'like drill in the army, is only a means to an end. It is the method by which a huge machine is made to move - rather ponderously - but steadily and without confusion. ${ }^{13}$ Historians need to make themselves masters of that machinery in order to understand its motions and the manner in which bureaucracies frame political problems and prepare their solution.

This leads to a further consideration, a further refinement. I referred earlier to the differences in the manner in which countries approach international problems. In doing so I used a convenient short-hand. States are not 'black boxes' ${ }^{44}$, hermetically sealed against their surroundings but somehow interacting with them. The reality is more complex. At the time of the American revolution Edmund Burke wrote that he knew of no way to frame the indictment of a whole nation. By the same token, there is something unsatisfactory in the way historians have used - and still use - the name of country, its capital or even buildings and streets to denote international actors, as if No. 10 Downing Street, the Quai d'Orsay, the Wilhelmstrasse, the Quirinale, Pevcheski Most or 'Foggy Bottom' were something other than bricks-and-mortar edifices, as if they instructed diplomats abroad, weighed questions of war and peace or of neutrality, cheated, dissembled, lied or perpetrated genocide. I am guilty of it myself. We all do it; and historians will probably continue to do it, but it is only a form of shorthand.

\footnotetext{
${ }^{43}$ Memo. Sanderson, 'Observations on the Use and Abuse of Red Tape for the Juniors in the Eastern, Western, and American Departments' (private), Oct. 1891, Foreign Office Library. For the concept of 'knowledge-based organisations' see N. Stehrs, Knowledge Societies (London, 1994), 172-174.

44 Steiner, 'On Writing International History', 536; see also id. (ed.), The Times Survey of Foreign Ministries of the World (London, 1982).
} 
What is needed is 'a language and terminology which reflects more accurately the realities of power, influence and responsibility. ${ }^{45}$ To develop it, it is necessary to prize open the lids of those black boxes to discover the actors inside. Political history, and international history more especially, is saturated with human agency. This is relatively straightforward for the seventeenth century when one is dealing with a prince and a clutch of courtiers and consiglieri around him. It becomes more complicated with the passage of time, as military, commerce and finance departments began to intrude on international relations, later to be joined by bankers, traders and experts of various kinds. In the short twentieth century humanitarian problems acquired greater significance. Nongovernmental organisations, supranational bodies and media outlets began to jostle with the traditional foreign affairs apparatus and so added to the cacophony of voices to be studied. $^{46}$

Unsurprisingly, there has been a certain 'dépersonnalisation des événements', a tendency against which Raymond Aron warned nearly six decades ago ${ }^{47}$, and which enjoyed a late intellectual hegemony under the auspices of Gesellschaftsgeschichte and its methodological imperialism. ${ }^{48}$ People matter, however. It is they who make any

\footnotetext{
${ }^{45}$ D.C. Watt, 'Personalities', unpublished paper, Conference in Honour of D.C. Watt, London School of Economics, 28-30 June 1993, fo. 3; J. Black, 'Documentary Cultures and History: A Brief Statement', Journal for the Study of British Culture xvii, 1 (2010), 13-15.

${ }^{46}$ Exemplary Z. Steiner, 'Refugees: The Timeless Problem', in M. Fran and J. Reinisch (eds.), Refugees in Europe, 1919-1959: A Forty Years' Crsis? (London, 2017), 21-31; S.B. Snyder, Human Rights Activism and the End of the Cold War: A Transnational History of the Helsinki Network (Cambridge, 2011) and id., From Selma to Moscow: How Human Rights Activists Transformed U.S. Foreign Policy (New York, 2018). 'Humanitarianism' was not confined to the twentieth century, see D. Rodogno, Against Massacres: Humanitarian Intervention in the Ottoman Empire, 1815-1914. The Emergence of a European Concept and International Practice (Princeton, NJ, 2012), esp. 18-35.

${ }^{47}$ R. Aron, Dimensions de la conscience historique (Paris, 1961), 182-184.

${ }^{48}$ See the monumental Deutsche Gesellschaftsgeschichte, 1700-1990 (5 vols., Munich, 1987-2008) by H.-U. Wehler, head of the so-called 'Bielefeld-school', with its emphasis on industrial modernization and internal societal or ideological factors, which, he contended, conditioned foreign policy. Wehler partially recanted on some of his more strident views on the subject. While foreign affairs do not feature in the first two volumes, vol. iii, Von der "Deutschen Doppelrevolution" bis zum Beginn des Ersten Weltkriegs, 1849-1914 (Munich, 1995), 965-989 and 1145-1168, takes mainstream positions; vol. iv, Vom Beginn des Ersten Weltkriegs bis zur Gründung der beiden deutschen Staaten (Munich,
} 
system work, but the manner in which they conceptualize policy issues and frame their responses to them is shaped by the political system in which they operate. The role of individuals, their particular ideas, assumptions and beliefs about how they should act in the world, remain key to scholarly concerns. In politics, every action, be it in actual deed or in the shape of a policy recommendation, is based on a set of premises, values and axioms. The characteristics of an age are thus expressed also in the manner in which contemporaries sought to rationalize their particular situation, and perhaps more especially in the language and concepts in which such efforts were framed. These concepts, or 'cognitive maps', distort reality and scale, just like any other cartographical projection, and so require calibration by the historian. As James Joll argued in his reflections on the 'unspoken assumptions' that underpin decision-making, politicians and officials are influenced by 'their own instinctive reactions, traditions and modes of behaviour. ${ }^{49}$ To illuminate the lineaments between the overt story of events and the 'cosmology of the actors' ${ }^{50}$ the international historian needs to explore the social background, educational experiences, and recruitment processes of the power elites. In this way it is possible to gauge notions about foreign policy on which contemporaries based their decisions. This set of accepted understandings and unexpressed assumptions, the 'official mind', is the product of a historical socialization progress. ${ }^{51}$

2003), 646-651, treats foreign policy exclusively in the context of the Führer myth; see also the thoughtful discussion by H. Afflerbach, 'Die Herausforderung der Diplomatiegeschichte durch das Konzept der Gesellschaftsgeschichte', in Bericht über den 22. Österreichischen Historikertag in Klagenfurt in der Zeit vom 4. bis 7. Mai 1999 (Vienna, 2002), 40-46, and also for a recent assessment P. Nolte, Hans-Ulrich Wehler: Historiker und Zeitgenosse (Munich, 2015), 87-104.

49 J. Joll, 1914: The Unspoken Assumptions. An Inaugural Lecture (London, 1968), 6-7; see already A.J.P. Taylor, The Italian Problem in European Diplomacy, 1847-1849 (Manchester, 1934), 1.

${ }^{50}$ M. Bentley, 'Politics, Doctrine and Thought', in id. and J. Stevens (eds.), High and Low Politics in Modern Britain (Oxford, 1986), 130. The problem of intentionality and motivation remains a thorny one, see Q. Skinner, Visions of Politics, i, Regarding Method (Cambridge, 2002), 90-102.

51 See T.G. Otte, The Foreign Office Mind: The Making of British Foreign Policy, 1865-1914 (Cambridge, 2011). 
Occasionally, international historians will deal with exceptionally gifted statesmen, who had a clear strategic conception of their policies. Olivarez and Richelieu, Chatham and Frederick II and even Kaunitz were in a class of their own, and so were Metternich, Bismarck and Salisbury or, in more recent times, Henry Kissinger and Helmut Schmidt, to which motley crew we may now have to add Joseph Stalin. ${ }^{52}$ More often than not, policy-making was more ragged around the edges, more haphazard in its conception and less consistent in its execution than historical reconstructions might suggest; and the historian has to resist the temptation of accepting unquestioningly the perspectives offered by the 'official mind' as found in departmental paper trails. It is important, therefore, to identify and differentiate the preoccupations and perceptions of policy-makers. Perceptions may distort, but they are decisive. They are the filter through which information passes, however selectively, and is then processed, no matter how incompletely or incompetently. ${ }^{53}$ This filter is to no small degree also conditioned by differences in generational experiences. Nothing is more easily recognizable than a political generation; few phenomena are more difficult to define than this one. A generation is not so much a question of birth dates and age cohorts, but rather one of a collective consciousness of common formative experiences. It is not a narrowly defined chronological phenomenon; rather it is 'a socio-historical location'. ${ }^{54}$

\footnotetext{
52 Exemplary D. Milne, Worldmaking: The Art and Science of American Diplomacy (2015); K. Spohr, The Global Chancellor: Helmut Schmidt and the Reshaping of the International Order (Oxford, 2016); for Stalin's strategic acumen see D. Reynolds and V. Pechatnov (eds.), The Kremlin Letters: Stalin's Wartime Correspondence with Churchill and Roosevelt (New Haven, CT, 2018).

${ }^{53}$ R. Jervis, Perception and Misperception in International Politics (Princeton, NJ, 1976, remains the locus classicus for this topic.

${ }^{54}$ R. Wohl, The Generation of 1914 (London, 1980), 81. The seminal text on the problem of political generations remains Karl Mannheim's essay in Wissenssoziologie, ed. K.H. Wolff (Frankfurt, 1964), 509-565; also the essays in H. Berghoff (ed.), History by Generation: Generational Dynamics in Modern History (Göttingen, 2013).
} 
At this level, international history needs to be set in different national contexts. It has to be, both, international and national. They are two sides of the same coin, and neither can be understood without reference to the other. This is not to blur, in a more or less elegant way, the issue of the Primat der Innenpolitik vs Primat der Aussenpolitik that so preoccupied scholars in the 1960s and 1970s in the aftermath of the Fischer controversy about the origins of the First World War. ${ }^{55}$ Rather it is meant to stress the inseparability of the external and domestic spheres, even if one might not wish to go so far as two historians of post-1945 US foreign policy who coined the term 'intermestic' to signify the degree to which the two were so enmeshed that disentangling them makes no analytical sense. ${ }^{56}$ This is perhaps a neologistic bridge too far, one, at any rate, which this particular historian's horses shy to cross. As an insight it is also not particularly novel. Scholars of early modern Europe, for instance, have long appreciated the internal, ideological or religious roots of the aggressive foreign policy of the Electors of the Palatinate from the mid-sixteenth century up to the outbreak of the Thirty Years' War. For the twentieth century, recent studies have convincingly mapped the swings of interwar Soviet foreign policy onto Moscow's changing domestic priorities. ${ }^{57}$

55 H. Böhme, "Primat" und "Paradigmata": Zur Entwicklung einer bundesdeutschen Zeitgeschichtsschreibung am Beispiel des Ersten Weltkrieges', in H. Lehmann (ed.), Historikerkontroversen (Göttingen 2000), 31-86; J.W. Langdon, July 1914: The Long Debate, 19191990 (Oxford, 1991); and also with special emphasis on the debate in Germany, see J.A. Moses, The Politics of Illusion: The Fischer Controversy in German Historiography (New York, 1975); W. Jäger, Historische Forschung und politische Kultur in Deutschland: Die Debatte um den Ausbruch des Ersten Weltkriegs, 1914-1980 (Göttingen, 1984).

${ }^{56}$ C. Campbell and F. Logevall, America's Cold War (Cambridge, MA, 2012); see also my 'War, Revolution, and the Uncertain Primacy of Domestic Politics', R.N. Rosecrance and S.E. Miller (eds.), The Next Great War?: The Roots of World War I and the Risk of U.S.-China Conflict (Cambridge, MA, 2015), 103-125.

57 See, e.g., C.-P. Clasen, The Palatinate in European History, 1555-1618 (Oxford, 1963), 5-19 et passim; P. Krüger, Die Beziehungen der Rheinischen Pfalz zu Westeuropa: Die auswärtigen Beziehungen des Pfalzgrafen Johann Casimir, 1576-82 (Munich, 1964); G. Roberts, 'The Fascist War Threat and Soviet Politics in the 1930s', in S. Pons and A. Romano (eds.), Russia in the Age of Wars, 
There are other 'realities behind diplomacy' that cannot be ignored. Tellingly, Pierre Renouvin and Jean-Baptiste Duroselle divided their broad survey of international history into two sections, of which the first offered a Braudelian analysis of "les forces profondes', the underpinning structural elements of international relations, and the other an 'histoire événementielle' ${ }^{58}$ Indeed, international historians ignore at their peril the interaction between economics and strategy. ${ }^{59}$ Appreciating such connections throws into sharper relief global connections. The end of the American civil war illustrates this point, for its effects extended well beyond post-bellum US politics and society. The resumption of cotton exports after 1865 led to a glut on the markets, and plunged the mono-cultures of Cuba and Egypt into deep financial crises. In turn, these led, first, to Britain and France taking control of Egyptian finances and, ultimately, the British occupation of the country, and so raised the curtain on nearly a quarter of a century of heightened Anglo-French antagonism. The Cuban crisis was a contributing factor to the collapse of the first Spanish republic in 1874, and, over time, to the Spanish-American war in 1898. Furthermore, the American war tempted the Emperor Napoleon III to meddle in Mexican affairs, so laying bare the limits of French power, a revelation the full import of which was not lost on Bismarck - with momentous consequences for

1914-1945 (Milan, 2000), 147-58; D.R. Stone, Hammer and Rifle: The Military of the Soviet Union, 1926-1933 (Lawrence, KS, 2000), 1-7.

${ }^{58} \mathrm{P}$. Renouvin and J.-B. Duroselle, L'Introduction à l'histoire des relations internationales (Paris, 1964). In his introduction to his series Histoire des Relations Internationales, Renouvin stressed the tension between 'l'influence primordiale des hommes' and 'les "forces profondes", id., 'Introduction Générale', in F.-L. Ganshof, Histoire des Relations Internationales, i, Le Moyen Age (Paris, $2^{\text {nd }}$ ed. 1958), here xii-xiii. Already two decades earlier, he had stressed the importance of economics and finance when discussing preparations for an Anglo-French historical conference in 1940 (!), Renouvin to Webster, 30 Apr. 1940, Webster MSS, 7/1/78.

${ }^{59}$ P.M. Kennedy, The Rise and Fall of the Great Powers: Economic Change and Military Conflict from 1500 to 2000 (London, 1989 (pb)), xv; see also G.-H. Soutou, L'or et sang: Les buts de guerre économique de la Première Guerre Mondiale (Paris, 1989), 845-851. 
Europe. ${ }^{60}$ The particular challenge for the historian of international relations, then, is to place events within the broader context of longer-term historical processes, without succumbing to the sombre grandeur of economic determinism, and so 'miss[ing] the forest for the lumber industry. ${ }^{91}$

No less important is the military dimension of international history. In a quasianarchic international environment states pursue, and are exposed to, a type of competition in which military technology is a major component. Arms races have their own historical dynamic of qualitative leaps, quantitative advances and geopolitical spread; and they have significant political consequences. There was, as David Stevenson has shown for the years before 1914, no simple one-way road to world war, but the dynamic of armaments competitions on land and at sea contributed to a growing sense of mutual insecurity, and this became a critical problem in great power relations. ${ }^{62}$

Consideration of these aspects leads to a wider systemic point. The interaction between states, the causes of war, the challenges of crisis management and the problems of peace-making are the principal focus of international history. As Metternich ruminated in later life:

\footnotetext{
${ }^{60}$ For general reflections see D. Landes, 'What Room for Accident in History?: Explaining Bug Changes by Small Events',, Economic History Review, n.s. xlvii, 4 (1994), 637-56; for the events referred to, see H. Feis, Europe, the World's Banker: An Account of European Foreign Investments and the Connection of World Finance with Diplomacy before World War I (New York, 1965), 382-90; H. Geuss, Bismarck und Napoleon III.: Ein Beitrag zur Geschichte der preussisch-französischen Beziehungen, 1851-1871 (Cologne and Graz, 1959), 152-156.

${ }^{61}$ Paul Schroeder's apt criticism of Gesellschaftsgeschichte, id., The Transformation of European Politics, 1763-1847 (Oxford, 1994), x; for general thoughts on the problems of historical processes, see C. Meier, 'Fragen und Thesen zu einer Theorie historischer Prozesse', in K.G. Faber and C. Meier (eds.), Theorie der Geschichte: Beiträge zur Historik, ii, Historische Prozesse (Munich, 1978 (pb.)), 11-66.

62 D. Stevenson, Armaments and the Coming of War: Europe, 1904-1914 (Oxford, 1996). The classic study of arms races remains H. Bull, The Control of the Arms Race (London, 1961); for further thoughts see J.T. Sumida and D.A. Rosenberg, 'Machines, Men, Manufacturing, Management and Money: The Study of Navies as Complex Organizations and the Transformation of Twentieth-Century Naval History', in J.B. Hattendorf (ed.), Doing Naval History: Essays Towards Improvement (Newport, RI, 1995), 25-40.
} 
Since the isolated state exists no more and could only be found in the annals of antiquity or in the abstractions of so-called philosophers, one has to keep in view constantly the society of states, which is one of the essential conditions of the contemporary world. Thus every state has ... also those [interests] which it shares with the other states ... . The great axioms of political science arise from the recognition of the true interests of all states; in their general interests resides the guarantee of their existence, whereas particular interests, which the manoeuvres of the moment often invest with great importance ..., are of only relative and secondary value. History teaches us that every time a state's particular interests collide with the general ones, and the latter are neglected in the vigorous pursuit of the former, this has to be viewed as an exceptional case, an instance of disease, the spread or healing of which decides about the state's impending decay or renewed flourishing. What characterises the modern world ... is this tendency of states to form close societal bonds. Modern history ... shows us the application of the principle of solidarity and equilibrium and offers the spectacle of the united efforts of several states against the supremacy of one power in order to spread of its influence and to force its return to the common law. Maintaining international relations on the basis of reciprocity ... now forms the essence of politics, of which diplomacy is only the daily application. ${ }^{63}$

The chancellor's reflections offer two important insights: that the permanent and regular linkages and interactions between states create a form of system; and, secondly, that one of the system's goals is its own preservation. To maintain it states, in their international practice, tend to establish basic rules and norms of behaviour to regulate competition and to temper violence. It is a sort of 'grammar' and an agreed toolkit of international politics. As Paul W. Schroeder, the historian of Metternichean great power politics, has argued, the states system also has an enabling function: 'Every international system, to be stable and durable, has to provide certain collective or public goods for at least the major participants - general peace, reasonable security from attack, recognition of status, sanctity of contracts, a general expectation that promises and commitments will be fulfilled and violators curbed or punished, and so on. ${ }^{64}$

\footnotetext{
${ }^{63}$ C. von Metternich, 'Autobiographische Denkschrift', R. von Metternich-Winneburg and A. von Klinkowström (eds.), Aus Metternich's nachgelassenen Papieren (8 vols., Vienna, 1881) i, 33-35.

${ }^{64}$ P.W. Schroeder, "Systems” and Systemic Thinking in International History', International History Review xv, 1 (1993), 128; and also J.S. Levy, 'The Theoretical Foundations of Paul W. Schroeder's International System', International History Review xvi, 4 (1994), 715-45; R. Rosecrance and Z. Steiner, 'History and Neorealism Reconsidered', in iid. (eds.), History and Neorealism (Cambridge,
} 
International history proper is impossible unless it contemplates the systemic background against which foreign policy is formulated and then executed. Some historically-minded International Relations scholars, such as Martin Wight, have emphasized the existence of structures within the system ${ }^{65}$; others have suggested that a more systemic approach furnishes an opportunity for identifying patterns in the apparently random and chaotic behaviour of sovereign states at any stage in the past. ${ }^{66}$ Such approaches go a little against the grain of the historian's engrained ideographic inclinations, against 'our congenital distrust of theory and our insistence upon the uniqueness of the historical event. ${ }^{, 67}$ Even so, perhaps '[h]istory is too important to be left to the historians' alone, as Christopher Thorne once argued. The pursuit of history ought to involve 'border crossings' - the title of one of Thorne's books - intellectual journeys across the lines of demarcation between various cognate disciplines of the humanities and social sciences. ${ }^{68}$ Enterprises of this kind can be journeys of discovery, productive of fresh insights and stimulating cross-fertilisation. And yet, crossing borders means recognizing their existence. Not to do so runs the risk of blundering blindly across the lines and perhaps also being left stranded in methodological no-man's land, or, indeed, becoming entangled in the barbed wire fencing along the frontier, from

2010), 341-65; G. Lundestad, The Rise and Decline of the American "Empire": Power and Its Limits in Comparative Perspective (Oxford, 2012), 150-74; for a sceptical view, E. Ingram, 'The Wonderland of the Political Scientist', International Studies xxii, 1 (1997), 53-63.

${ }^{65}$ M. Wight, Power Politics, ed. H. Bull and C. Holbraad (London, $2^{\text {nd }}$ ed. 1986); for Wight and his intellectual endeavours, individual and collective, see B. Vigezzi, The British Committee on the Theory of International Politics (1954-1986): The Rediscovery of History (Milan. 2005), 18-21 et passim; important also J.A. Maiolo, 'Systems and Boundaries in International History', International History Review xl, 3 (2018), 576-591.

${ }^{66}$ For a survey see R. Jervis, 'Systems Theories and Diplomatic History', in P.G. Lauren (ed.), Diplomacy: New Approaches in History, Theory and Policy (New York, 1979), 212-244.

${ }^{67}$ G.A. Craig, 'The Historian and the Study of International Relations', American Historical Review lxxxviii, 1 (1983), 9.

${ }^{68}$ C. Thorne, Border Crossings: Studies in International History (Oxford, 1988), 12; also id., The Far Eastern War: States and Societies, 1941-45 (London, 1986 (pb)), xxii. 
which no amount of habitual nodding to Bourdieu or Foucault or Said can free the historian. Crossing borders in a meaningful way, then, means acknowledging them in order to redefine them, unless one intends to eradicate them altogether. ${ }^{69}$

As our Circle Line train proceeds on its journey, it is becoming clear just what a vast terrain international history has come to cover. Some scholars, indeed, have concluded that the discipline is not so much 'a methodological prescription' but rather a 'vast empty plain with undetermined borders. ${ }^{70}$ There have, moreover, been forays onto its terrain. International history, just as history in general, has been challenged from different directions by post-modernists and post-structuralists, and, more recently, by proponents of a 'culturalist international history'. ${ }^{71}$ In practice, however, there are pitfalls. In emphasizing the self-interested nature of all definitions of the national interest (- what were they expecting?-) culturalists wind up merely 'universalising the domestic. $^{72}$ In short, they have begun to de-politicize and de-internationalize international history, and so risk becoming atomistic and solipsistic. This trend has not been checked by the recent turn to global and transnational history with its sharper focus

\footnotetext{
${ }^{69}$ For this see Fernand Braudel, who advocated 'briser les frontières entre specialistes', id., 'L'histoire des civilisations: le passé explique et le présent', in id., Écrits sur l'histoire (Paris, 1969), 299. For an intelligent use of Bourdieu see P. Jackson, Beyond the Balance of Power: France and the Politics of National Security in the Era of the First World War (Cambridge, 2014), and his earlier reflective piece, 'Pierre Bourdieu, the "Cultural Turn", and the Practice of International History', Review of International Studies xxxiv, 2 (2008), 155-181.

${ }^{70}$ E.S. Rosenberg, 'Walking the Borders', in M.J. Hogan and T.G. Paterson (eds.), Explaining the History of American Foreign Relations (New York, 1991), 24-5. This is not a new discovery, see W.N. Medlicott, 'The Scope and Study of International History', International Affairs xxxi, 4 (1955), 415 416. ${ }^{71}$ A.J. Rotter, 'Culture', in P. Finney (ed.), Palgrave Advances in International History (Basingstoke
and New York, 2005), 270; L. Jordanova, History in Practice (London, 2000), 41-42.

${ }^{72}$ V. Dekpat, 'Cultural Approaches to International Relations: A Challenge?', in J.C.E. Gienow-Hecht and F. Schumacher (eds.), Culture and International History (Oxford, 2004), 185-186.
} 
on border-transcending phenomena, such as economic integration or migration, political and social movements, or the dissemination of ideas and the growth of professional networks. ${ }^{73}$

Such approaches can help to stimulate fresh thinking and, at a minimum, broaden and deepen our understanding of the past. They contain an analytical flaw, however, in that they cannot without difficulty relate the transnational sphere to the operations of the state system. Indeed, it is notable that in transnational narratives the state emerges as a resistant element that impedes progress, a roadblock to be overcome in the onwards march towards a global society. ${ }^{74}$ It thus projects contemporary concerns and ideological positions back into the past, which is a category error of historical analysis, albeit one that can never be entirely avoided ${ }^{75}$ In a sense it is a latter-day Whig interpretation of globalization - and it puts the horse before the cart: a managed and relatively stable, rules-based international order facilitated the growth of the transnational sphere, and not vice versa. As that fine, liberal American historian C. Vann Woodward once noted: 'The demagoguery, the cant and the charlatanry of historians in the service of fashionable causes can at times rival that of politicians. ${ }^{76}$

Amongst the new angles on international history that have been suggested are that of gender and, more recent still, emotion. Frank Costigliola, for instance, has argued that engendering diplomatic language can reveal 'how emotive meanings can constrain

\footnotetext{
${ }^{73}$ Mazower, No Enchanted Palace, 103-48; A. Bashford, 'Populations, Geopolitics and International Organizations in Mid-Twentieth Century', Journal of World History xix, 3 (2008), 327-348.

${ }^{74}$ See A.-C.L. Knudsen and K. Gram-Skøldager, 'Historiography and Narrative in Transnational History', Journal of Global History xi, 2 (2014), 143-61.

${ }^{75}$ See Lucien Fevre's pertinent comments id., 'De 1892 à 1933: examen de conscience d'une histoire et d'un historien', in id., Combats pour l'Histoire (Paris, 1953), 9-10; and his observations on contemporary habits to project twentieth-century strategic interests along the Rhine frontier back into the past, id., 'L'homme d'État ce qu'il n'est point', in A.B. Duff and F. Galy (eds.), Hommes d'État (3 vols., Paris, 1936) iii, esp. 719-20.

${ }^{76}$ C.V. Woodward, 'Clio with Soul', in B. Rustin (ed.), Black Studies: Myth and Reality (New, 1969), 29; and id., Thinking Back: The Perils of Writing History (Baton Rouge, LA, and London, 1986).
} 
and actively shape rational analysis'. Thus, George F. Kennan's ' $\mathrm{X}$ '-article corresponded to popular attitudes, prevalent in American society, about gendered imagery and stereotypes. Similarly, the intensely emotional response by American officials to anti-American rhetoric during the early stages of the Cuban revolution in 1959-60 established the trajectory of US-Cuban relations for the following six decades. ${ }^{77}$ It is difficult to see how far this side of the argument can be pushed in practice. The, thus far, small number of female decision-makers is one obvious obstacle. ${ }^{78}$ It is remarkable also how recent studies of, for instance, the Empress Maria Theresa or of that other gloriana imperatrix, Margaret Thatcher, analyze their subject in terms of realpolitik or ideology more than gender. ${ }^{79}$

In recent years studies of ceremonial and other procedural practices in inter-state relations have grown in volume, range and depth; and they add to our understanding of the externalities of past diplomatic practice. ${ }^{80}$ Another interesting and fertile area for

\footnotetext{
${ }^{77}$ F. Costigliola, 'The Nuclear Family: Tropes of Gender and Pathology in the Western Alliance', Diplomatic History xxi, 2 (1997), 183; id., 'Unceasing Pressure for Penetration: Gender, Pathology, and Emotion in George Kennan's Formation of the Cold War', Journal of American History lxxxiii, 4 (1997), 1309-39; W. LeGrande, 'Anger, Anti-Americanism and the Break in U.S.-Cuban Relations', Diplomatic History xli, 1 (2017), 104-105; also N. Eustace et al., 'AHR Conversation: The Historical Study of Emotions', American Historical Review cxvii, 5 (2012), 1487-1530; E.S. Rosenberg, 'Gender', Journal of American History lxxvii, 1 (1990), 116-24. Kennan's biographer does not seem to be struck by such insights, J.L. Gaddis, George F. Kennan: An American Life (New York, 2011), 249275. See also K.O. Morgan's wise counsel 'never [to] be unduly rationalist' when writing political history, id., 'Political History', in J. Gardiner (ed.), What is History Today ... ? (Basingstoke and New York, 1988), 29.

${ }^{78}$ For a recent study of the slow opening of the diplomatic profession to women in Britain see $\mathrm{H}$. McCarthy, Women of the World: The Rise of the Female Diplomat (London, 2014). K. Garner, Women and Gender in International History: Theory and Practice (London, 2018) makes a valiant effort, but is stronger on a theoretical critique of what the author takes to be international practice.
}

${ }^{79}$ T. Lau, Die Kaiserin: Maria Theresia (Vienna, 2016) offers some thoughts on the 'maternal' persona of the empress, but her foreign policy shows no specifically 'female' quality; see also B. StolbergRilinger, Maria Theresia: Die Kaiserin in ihrer Zeit (Munich, 2017), who however stresses 'matriarchal' aspects in general; cf. S. Dixon, Catherine the Great (Abingdon, 2001); for Thatcher, see P. Sharp, Thatcher's Diplomacy: The Revival of British Foreign Policy (London, 1997).

${ }^{80}$ I. Fenton, The Ceremonial City: Memory and Myth in Renaissance Venice (New Haven, CT, 2007), 153-215; E.D. Petritsch, 'Interkulturelle Diplomatie zwischen Habsburgern und Osmanen: Fragen und Probleme (16.-18. Jahrhundert)', in B. Tremml-Werner and E. Crailsheimer (eds.), Audienzen und Allianzen: Interkulturelle Diplomatie in Asien und Europa vom 8. bis zum 18. Jahrhundert (Vienna, 2015), 184-200; A. Fahrmeir, 'Fragile Boundaries and Personal Action: The Nineteenth Century as a 
international historians has been the aspect of myth, or better, collective beliefs, and their relationship with decision-making through historical analogies. 'Versailles', 'Munich', 'Yalta' are constructed historical shorthands that imply collectively accepted 'lessons of the past' ${ }^{81}$ Often they reflect a historical sensibility that relies on analogies to provide orientation in the confused present and an interpretative anchorage in the fast flowing current of events. ${ }^{82}$ Some international historian have taken a leaf out of the work of the polemicist Edward Said to construct 'orientalist' interpretations of American foreign policy. Others have applied this idea of 'otherness' or 'alterity' to South Eastern Europe and have suggested 'Balkanism' as shaping Western policy in that region. ${ }^{83}$ Here, as with gendered approaches, there is the danger of self-indulgent reification. In its wake, an intellectual tendency is privileged over other factors, and is so turned into a single, quasi-monolithic explanatory force ${ }^{84}$ It is a reminder that the value of history as a training of judgment and of imagination is the more limited, the narrower and the more exclusive its focus becomes.

Period of Transformation', in id., G. Hellmann and M. Vec (eds.), The Transformation of Foreign Policy: Drawing and Managing Boundaries from Antiquity to the Present (Oxford, 2016), 127-140.

${ }^{81}$ E.R. May, "Lessons of the Past”: The Use and Misuse of History in American Foreign Policy (New York, 1973); B.W. Schapers, Het trauma van Munchen (Amsterdam, 1975); C. Buffet and B. Heuser (eds.), Haunted by History: Myths in International Relations (Oxford, 1998); J. Record, The Spectre of Munich: Reconsidering Lessons of Appeasing Hitler (Washington, DC, 2006); P.J. Beck, Using History, Making British Foreign Policy: The Treasury and the Foreign Office, 1950-1976 (Basingstoke and New York, 2006); and also the observations by J. Tosh, Why History Matters (Basingstoke and New York, 2008), 62-68.

${ }^{82}$ See H.W. Brands and J. Suri, 'Thinking about History and Foreign Policy', iid. (eds.), The Power of the Past: History and Statecraft (Washington, DC, 2015), 14-16, and the other essays in this volume.

${ }^{83}$ See e.g. A.J. Rotter, 'Saidism without Said: Orientalism and US Diplomatic History', American Historical Review cv, 4 (2005), 1205-1217; and M. Todorova, Imagining the Balkans (Oxford, rev. ed. 2009), 116-160 et passim. For an important corrective of Said, see R. Unwin, For the Lust of Knowing: The Orientalists and their Enemies (London, 2007 (pb.)), 141-188.

${ }^{84}$ An egregious example of this is M. Todorova, 'Outrages and their outcomes' [review of C. Clark, The Sleepwalkers: How Europe went to war in 1914 (London, 2012)], The Times Literary Supplement, no. 5727 (4 Jan. 2013), 9-10. 
Undoubtedly, these new approaches add to our understanding of international history; they can enrich it: 'Nothing exists in some hermetically sealed sub-division of our imagination or academic discipline. Everything is related to everything else and light shines forth from distant places. ${ }^{95}$ But 'Mind the Gap'. Post-modernity seeks to dissolve history. It aims at nothing less than at 'liberat[ing] us from the coercive idea of reality and truth'- in short it seeks ultimate liberation from the tyranny of the past itself. ${ }^{86}$ By reducing grand narratives to strings of little, decontextualized stories, and by marginalizing within them the passage of time, they render insignificant, if not indeed meaningless, the differences caused by the passage of time. Those who consider the past merely a construct fail to appreciate just how constructed - if not contrived - their own thinking is. Their dream of the endless liberation of the individual has turned into a perpetual nightmare of a quasi-nomadic life for disillusioned cognoscenti and discalced discoursarians amidst a growing desert of a senseless and demystified present. It is but a small step from here to cultural pessimism. ${ }^{87}$ It also ignores the singularity of the past and runs the risk of reducing it to an amalgam to a priori answers: 'The main events are unique, irreversible and unrepeatable. A historical truth is true only once. ${ }^{, 88}$

\footnotetext{
${ }^{85}$ F. Stern, 'The Historian and His Debts', The Rothschild Archive Annual Review (2003-4), 21.

${ }^{86}$ G. Himmelfarb, 'Telling It as You Like It', Times Literary Supplement, no. 4692 (16 Oct. 1992), 1215; see also C. Norris, The Truth about Postmodernism (Oxford, 1993); T. Eagleton, The Illusion of Postmodernity (Oxford, 1996); and also R.J. Evans, In Defence of History (London, rev. ed. 2000), 254-316 et passim.

${ }^{87}$ See already the prescient warning by E. Troeltsch, Der Historismus und seine Probleme (Tübingen, 1922), 241: 'The destruction of historical Bildung and of historical knowledge could only be understood as a decision for barbarism and could only be accomplished on the return to barbarity in all other areas of life. [...] It is the depressing and long drawn out death of superannuated cultures, not exuberant power and freshness.' For the consequences see F. Stern, The Politics of Cultural Despair: A Study of the Rise of the Germanic Ideology (Berkeley, CA, 1961).

${ }^{88}$ C. Schmitt, 'Die geschichtlichen Strukturen des heutigen Weltgegensatzes von Ost und West: Bemerkungen zu Ernst Jüngers Schrift "Der Gordische Knoten"', in id., Staat, Grossraum, Nomos: Arbeiten aus den Jahren, 1916-1969, ed. G. Maschke (Berlin, 1995), 531. Caveat lector!: for the context see G. Balakrishnan, L'Ennemi: Un portrait intellectuel de Carl Schmitt (Paris, 2000), 307321; W. Schmidt-Biggemann, Geschichte als absoluter Begriff: Der Lauf der neueren deutschen Philosophie (Frankfurt, 1991), 65-75 and 106-110.
} 
These new approaches, moreover, cannot replace the concern with top-level decision-making, more especially when things are on the cusp of peace and war. There has been, as David Reynolds has noted, 'a recurrent "diplomatic twitch" in the saga of international history'. ${ }^{89}$ It is 'the history of decision-making' and of those who made decisions. $^{90}$ It is concerned with judgment and decisions in always specific circumstances. This is the 'inner circle' of international history. To dismiss it as desiccated diplomatic calculations is to fail to understand the sensibilities of a past age. The irony of recent approaches is that they employ methods that prevent them from discovering those past sensibilities.

Historians change the questions they ask of the past. That is inevitable: 'The subject we historians examine is static. It is just we that are whisked along by time speeding away from the scene of action. Since our audience is on the same train we cannot get off it, while we still live. ${ }^{91}$ As the train moves away, so new vistas open up. To that extent history is, indeed, inseparable from the historian; and it is for this reason that historians keep writing history anew. ${ }^{92}$

If the train ever did travel across an empty plain, that might have been true of the post-Cold War world, when it was considered to be safe to declare the 'end of history'

\footnotetext{
${ }^{89}$ Reynolds, 'Diplomatic Twitch', 91.

${ }^{90}$ F.R. Bridge, 'Österreich(-Ungarn) unter den Grossmächten', in A. Wandruschka and P. Urbanitsch (eds.), Die Habsburgermonarchie, 1848-1918, vi/1, Die Habsburgermonarchie im System der internationalenn Beziehungen (Vienna, 1989), 368.

${ }^{91}$ Watt to Zara Steiner, n.d. ['Monday'] [after 13 Sept. 2002, as the letter makes reference to Steiner's review in The Times Literary Supplement no. 5189 (13 Sept. 2002)]. I am grateful to Dr Steiner for sharing this document with me.

92 Paul Valery, as quoted in H.-I. Marron, De la connaissance historique (Paris, repr. 1975), 47; H. Lübbe, 'Traditionsverlust und Fortschrittskrise', in id., Praxis der Philosophie, Praktische Philosophie, Geschichtstheorie (Stuttgart, 1978), 117.
} 
and with it to proclaim the triumph of liberal democracy. ${ }^{93}$ Things look different now. History does not seem to have come to a full stop. Western values are under siege abroad and at home; and the international landscape is far from empty now as old and new fault-lines open up, new mountain ranges emerge and nasty crevices appear. Hybrid and non-linear types of warfare challenge traditional thinking about conflict; and international cooperation and the organizations created to facilitate it seem to be in retreat. ${ }^{94}$ While culturalists, transnationalists and globalists fiddle out their reedy tunes, the world - past and present - is burning. It is scarcely surprising that, in the immediate aftermath of the events of 9/11, a prominent American historian thought that 'the next big thing', the next 'turn', would be 'some kind of revival or refashioning of diplomatic and/or military history.' International history after all is a form of 'disaster studies'. What was more surprising was that the author of these lines was a leading exponent of the New Cultural History in the United States. ${ }^{95}$

This takes me back to my opening comments about relevance and the concern of the pioneers of international history with the practical applicability of their scholarly insights. It would be absurd to suggest that having produced a doctoral thesis on Metternich somehow makes for a good future foreign minister - though in that particular

\footnotetext{
${ }^{93}$ F. Fukuyama, 'The End of History', The National Interest xvi (Summer 1989), 3-18, and id., The End of History and the Last Man (New York, 1992). The mood has steadily soured since, see W.R. Mead, 'The Return of Geopolitics', Foreign Affairs xliii, 3 (2014), 69-79; J. Welsh, The Return of History: Conflict, Migration and Geopolitics in the Twenty-First Century (Toronto, 2016); B. Emmott, The Fate of the West: The Battle to Save the World's Most Successful Political Idea (London, 2017); J. Zielonka, Counter-Revolution: Liberal Europe in Retreat (Oxford, 2018).

94 T.G. Otte, 'The Waning of the Post-War Order: Historical Reflections on 2016 and the Emergence of a Twenty-First Century World Order', in R. Jervis, F.J. Gavin, J. Rovner and D. Labrosse (eds.), Chaos in the Liberal Order: The Trump Presidency and International Politics in the 21st Century (New York, 2018), 158-171.

${ }^{95}$ L.M. Hunt, 'Where Have All the Theories Gone?', Perspectives xl, 1 (Mar. 2002), 5-7. https://www.historians.org/publications-and-directories/perspectives-on-history/march-2002/wherehave-all-the-theories-gone ; see also her Writing History in the Global Era (New York, 2014), 1-2, in which she warned of a general crisis of history; and the attempt to revive longue durée perspectives by J. Guldi and D. Armitage, The History Manifesto (Cambridge, 2014), 6-9 and 117-19.
} 
case the claim is a strong one. ${ }^{96}$ My aspiration here is more modest - and more ambitious. International historians must be like Isaiah Berlin's fox who, unlike the hedgehog, knows many things but who understands that he can never grasp the ultimate cause of things. ${ }^{97}$ All knowledge is nothing but an approximation of the truth, fleetingly and imperfectly glimpsed.

Yet historians can shape opinion by using their expertise to suggest ways in which problems can be analyzed and to offer possible analogies with past patterns of behaviour, if only they remembered to communicate their thinking to a wider audience. ${ }^{98}$ If they do not, much of their work will be but a shallow-rooted flower, choked by a weedy growth of over-specialised erudition. At a very basic level, the best way of working through a problem is to create Taylor's timeline with its intersections, and explore the viewpoints of the other side, weigh the evidence and then suggest possible analogous situations. ${ }^{99}$ However great their intellectual and moral detachment, historians are committed to the society and its values that enabled them to remain so detached. Thomas Arnold was right: it is this that distinguishes them from antiquarians. After all, they are "member[s] of the polis and cannot watch its destruction without [themselves] being destroyed. ${ }^{, 100}$ In placing their expertise at the service of the polis,

\footnotetext{
${ }^{96}$ For some of this see S.R. Graubard, Kissinger: Portrait of a Mind (New York, 1973), 13-53; P.W. Dickson, Kissinger and the Meaning of History (Cambridge, 1978), 11-50; instructive also J. Sebenius, R.N. Burns and R.H. Mnookin, Kissinger the Negotiator: Learning from Dealmaking at the Highest Level (New York, 2018), xxii-xxiii.

${ }^{97}$ I. Berlin, The Hedgehog and the Fox: An Essay on Tolstoy's View of History, ed. H. Hardy (London, $2^{\text {nd }}$ ed. 2013), 1-2; see also J.L. Gaddis, On Grand Strategy (London, 2018), 295-313. ${ }^{98}$ For a powerful critique of postmodernity's narrow and unrewarding mindset see P. Mandler, History
and National Life (London, 2002).

${ }^{99}$ R. Neustadt and E.R. May, Thinking in Time: The Uses of History for Decision-Makers (New York, 1988), 232-46; also D. Kagan, 'A practical use for history', The New Criterion (Nov. 2014), 30-32.

${ }^{100}$ M. Howard, Lessons of History (Oxford, 1989), 20; see also the eloquent reflections by Mary Ann Glendon, a former US ambassador, on the temptations and dangers of intellectuals in politics, id., The Forum and the Tower: How Scholars and Politicians Have Imagined the World, from Plato to Eleanor Roosevelt (Oxford, 2011); and the recent plea by H. Brands and F.J. Gavin, 'This Historical Profession
} 
though, they must know what any statesman knows, that to act responsibly is to act with a clear sense of the limits of the possible. ${ }^{101}$

If history teaches anything, it is a certain sceptical mindset - '[t]here are discoveries to be made; but also there are habits to be formed', as Maitland put it. ${ }^{102} \mathrm{~A}$ particular current problem may not necessarily mean what it is said - often repeatedly to mean. We should seek to bridge the gap between scholarship and public policy. I am reluctant to sing the virtues of Clio the Muse in this respect, for all too often such exercises end in a dirge on her abuse. History is always vulnerable to attempts to exploit it for the needs of the present. ${ }^{103}$ The spectrum of such manipulations can range from forgeries, such as the Soviet fabrications about the Katyn massacres, to lazy labelling of the 'Munich' variety in political discourse, the 'histotainment' offered in the mass media or the political activism that targets suspected relics of colonialism in contemporary politics and society. ${ }^{104}$ Nor is there is any guarantee that the public or politicians will listen. Margaret Thatcher was famously not amused when, in early 1990, a group of

is Committing Slow-Motion Suicide', 10 Dec. 2018, https://warontherocks.com/2018/12/the-historicalprofession-is-committing-slow-motion-suicide/ and thirteen historians writing in The Times, 21 Dec. 2018.

${ }^{101}$ For Cicero this was the real science of politics, 'scientia sapienti', id., De Re Publica/De Legibus, ed. C.W. Keyes (London, 1928), bk. I, VI. 11.

102 F.W. Maitland, Domesday Book and Beyond: Three Essays in the Early History of England (Cambridge, 1897), 520; see also I. Berlin, 'General Education', id., The Power of Ideas, ed. H. Hardy (London, 2000), 214-23, and O. Marquand, 'Skeptiker', in id., Apologie des Zufälligen (Stuttgart, 1986), 6-10.

\footnotetext{
${ }^{103}$ Note that the muse's name is derived from $\kappa \lambda \varepsilon i \omega$, 'to celebrate'; for some context see M.I. Finley, 'Myth, Memory and History', in id., The Use and Abuse of History (London, 1986), 11-33. For an examination of the politicization of the past in Australia see S. MacIntyre and A. Clark, The History Wars (Melbourne, new ed. 2004).

${ }_{104}$ Record, Munich, 112-13. A useful documentation on Katyn is offered by A.M., Cienciala, N. Lebedeva and W. Materski (eds.), Katyn: A Crime Without Punishment (New Haven, CT, 2008). For history as entertainment and the mass media see L. Kaufmann, 'Être historien(ne) à l'ère de l'Histotainment' (15 Nov. 2016), https://lyonelkaufmann.ch/histoire/2016/11/15/etre-historienne-lerede-histotainment and P. Nolte, 'Öffentliche Geschichte: Die neue Nähe von Fachwissenschaft, Massenmedien und Publikum. Ursachen, Chance und Grenzen', M. Barricelli and J. Hornig (eds.), Aufklärung, Bildung, "Histotainment"?: Zeitgeschichte in Unterricht und Gesellschaft heute (Frankfurt, 2008), 131-46. Instructive for the motivations behind 'decolonising' activism the essays in R. Chantiluke, B. Kwomba and A. Nkopo (eds.), Rhodes Must Fall: The Struggle to Decolonise the Racist Heart of Empire (London, 2018).
} 
distinguished British and American historians failed to endorse her prejudices, personal and generational, against German unification. ${ }^{105}$ And even though Lloyd George, in 1919, had scholars of the calibre of Namier and Sumner, Temperley and Webster at his side, he was perfectly capable of ignoring them. He 'thought he knew more history than they [the experts]', Temperley noted in his diary: 'He decides by inspiration.' But the historians were not entirely without influence. On one occasion, as the Big Four were poring over maps in an effort to redraw boundaries, Lloyd George was puzzled because he could not find a place mentioned in the briefing papers. Where could it be? The scholarly advice was: 'If you take your great foot aside you'll see it!' He did, and he saw. ${ }^{106}$

Historical scholarship cannot predict the future. But it can advise politicians to tread warily; and it can warn the public to be watchful that politicians' big feet remain in reasonably safe places. But historical knowledge and understanding is more than a political health and safety device. At a time when enlightenment values are under siege, when expert views are summarily dismissed as irrelevant or as an irritant, when ignorance is celebrated as virtuous, and when truth and fiction no longer seem polar opposites - a development to which historians sadly have contributed - the need for intellectual courage and leadership has rarely been greater. It is better to light a candle than to curse the darkness. The historian's guttering 'lantern on the stern which shines only on the waves behind ${ }^{107}$ and the flickering light it sheds are perhaps not much, but they are better than nothing. 'When the past no longer illuminates the future',

\footnotetext{
${ }^{105}$ See Fritz Stern's recollections of the 1990 Chequers seminar id., Five Germanys I Have Known (New York, 2006), 467-9.

106 Temperley diary, 18 Apr. and 25 May 1919, Otte (ed.), Historian in Peace and War, 400 and 422.

${ }^{107}$ Samuel Taylor Coleridge, 18 Dec. 1831, Specimens of the Table-Talk of the Late Samuel Taylor Coleridge, ed. H.N. Coleridge (2 vols., New York, 1835) ii, 11. On the logical problems of predictions still relevant P. Medewar, 'Expectation and Prediction', in id., Pluto's Republic (Oxford, repr. 1990 (pb)), 298-310.
} 
Tocqueville noted, 'the spirit marches in darkness.' ${ }^{108}$ And it may well do so if we lose sight of the 'inner circle'.

108 A. de Tocqueville, De la democratie en Amerique; Souvenirs; l'Ançien Régime et la Revolution (Paris, 1986), 657; also E. Kahler, The Meaning of History (London, 1965), 219-220. 